\title{
PERSEPSI ULAMA DI KOTA LANGSA TENTANG GOLONGAN PUTIH
}

\author{
Mila Nurul Aisiyah \\ Sitti Suryani \\ Rasyidin
}

\begin{abstract}
ABSTRAK
Golput (golongan putih) adalah salah satu bentuk perlawanan terhadap praktik politik dari orang-orang yang kecewa terhadap penyelenggaraan negara dengan cara tidak memilih partai atau legislator (dalam pemilu legislatif) atau Presiden (dalam pemilu Presiden). Banyaknya pengamat politik mengatakan bahwa fenomena golongan putih ini merupakan bukti kekecewaan masyarakat akan kinerja politisi rakyat merasa "ditipu" dengan janji-janji manis pada saat kampanye, masyarakat merasa politisi tidak mampu mewakili kehendak rakyat dan melaksanakan janji-janjinya. Tingginya angka golongan putih dapat menurunkan legitiminasi pemerintah yang terbentuk dari hasil pemilihan umum, baik dalam proses pemilihan legislatif maupun pemilihan Presiden dan Wakil Presiden. Hasil penelitian ini menunjukkan bahwa persepsi ulama kota Langsa mengenai golongan putih yaitu golput tidak boleh karena diharamkan selama calon pemimpin tidak memenuhi syarat menjadi seorang pemimpin, dalam konsep Islam golput identik dengan orang yang tidak bertanggung jawab. Golput (golongan putih) dimata agama tidak benar dan dalam sudut pandang Islam golput bagian dari pelanggaran dan golput tidak boleh karena tidak ada maslahat yang dicapai dalam pemilu. Sedangkan argumen ulama di Kota Langsa tentang golongan putih yaitu golput dibolehkan, karena golput itu hak, sekaligus kewajiban bagi negara yang baik. Jika seseorang tidak mau menggunakan hak pilihnnya tidak bisa dipaksakan juga tetapi sebagai warga negara yang bertanggung jawab, masyarakat wajib memilih karena satu suara saja sangat berguna bagi kehidupan bangsa kedepannya. Sebagai warga negara yang baik sepatutnya harus bertanggung jawab dan ia tidak boleh meninggalkan hak pilihnya kerena ia sudah mengakui bahwa demokrasi sebagai cara untuk bernegara.
\end{abstract}

Kata Kunci : Persepsi Ulama, Golongan Putih

\section{PENDAHULUAN}

Sikap orang-orang golongan
putih dalam memilih memang
berbeda dengan kelompok pemilih
lain. Kaum golongan putih
menggunakan hak pilih dengan tiga
kemungkinan pertama menusuk lebih
dari satu gambar partai, kedua

menusuk bagian putih dari kartu suara, ketiga tidak mendatangi kotak suara dengan kesadaran untuk tidak menggunakan hak pilih. Bagi mereka memilih dalam pemilu sepenuhnya adalah kewajiban mereka dalam kaitannya dengan hak pilih ialah menggunakan secara bertanggung jawab dengan menekankan kata 
penyerahan suara, kepada tujuan pemilu tidak hanya membatasi pada penyerahan suara kepada salah satu pemilu. ${ }^{1}$

Sekarang ini muncul wacana tentang rekomendasi pengharaman golongan putih pada silaturahmi MUI Padang Panjang Sumatera Barat tanggal 23-26 Januari 2009 dalam pemilu disatu sisi ada politisi muslim menganjurkan untuk melakukan golongan putih dengan motivasi tertentu, tanggapan pun beragam ada yang menyatakan golongan putih itu haram dan mendorong MUI, NU dan Muhamadiyyah untuk menfatwakan golongan putih.Usulan tersebut menjadikan rekomendasi pengharaman golongan putih pada silaturahmi MUI di Padang Panjang tanggal 23-26 Januari 2009 dalam pemilu ijtima'ulama komisi fatwa seIndonesia III yang diselenggarakan dipadang panjang Sumatra Barat pada Tanggal 23-26 Januari 2009, golongan putih menjadi salah satu agenda pembahasan serius. $^{2}$

Banyaknya pengamat politik mengatakan bahwa fenomena golongan putih ini merupakan bukti kekecewaan masyarakat akan kinerja politisi rakyat merasa "ditipu" dengan janji-janji manis pada saat kampanye, masyarakat merasa politisi tidak mampu mewakili kehendak rakyat dan melaksanakan janji-janjinya. Tingginya angka golongan putih dapat menurunkan legitiminasi

\footnotetext{
${ }^{1}$ Gandang Ismara, Memahami Eksistensi Golongan Putih dalam Demokrasi, dalam http//lanskup artikel. Blogspot.com/2008/10/memahami-eksistensi -
}

pemerintah yang terbentuk dari hasil pemilihan umum, baik dalam proses pemilihan legislatif maupun pemilihan Presiden dan Wakil Presiden.

Kelompok gerakan Islam yang berkembang dengan ideologi anti demokrasi ini merupakan varian politik yang mengambil tindakan dan pendapat yang didasari atas berbagai pertimbangan dan sebab yang melatarbelakangi kemunculannya. Salah satu yang melatarbelakangi adalah kekecewaan politik dan adanya anggapan sistem yang ada sat ini tidak cukup mengakomodasi kepentingan dan ajaran kelompoknya. Keyakinan kuat yang kuat tumbuh menjadi kesadaran akan adanya ancaman eksistensi ajaran Islam pada akhirnya menempatkan barat beserta produk-produk sistem yang di lahirkan darinya sebagai musuh yang harus didekontruksikan keberadaannya dan di gantikan dengan sistem yang mereka yakini lebih islami serta layak menjadi sistem negara.

Akhirnya, pandangan dan tindakan ini membawa pengaruh terhadap partisipasi politik sebagai salah satu unsur keberlangsungan sistem politik di Indonesia. Salah satu pilihan politik itu adalah adanya tindakan apolitis atau tidak menggunakan hak politiknya, dalam pemilu baik untuk memilih maupun dipilih, atau lebih sering disebut

\footnotetext{
golongan putih-dalam. html. Diakses pada Tanggal 15 Juli 2009.

2 http//www.kompas.com. Diakses
} Pada Tanggal 10 Juli 2018 
dengan golongan putih lantaran tidak adanya ailiasi politik kearah manapun seperti halnya warna putih yang belum tercampur dengan warna lainya.

\section{Kecenderungan golongan} putih didalam pemilu di Indonesia mengalami trend kenaikan dari pemilihan satu ke peralihan lain meskipun tidak ada angka pasti apakah tingginya angka golongan putih itu disebabkan karena adanya gerakan anti demokrasi yang disuarakan beberapa gerakan Islam. akan tetapi, kekhawatiran hilangnya legitimasi pemerintahan yang terbentuk lantaran tingginya angka golongan putih menyebabkan MUI yang merupakan reprentasi pembuka agama Islam Indonesia mengeluarkan fatwa haram golongan putih bagi setiap muslim Indonesia selama masih ada calon pemimpin baik eksekutif maupun legislatif yang memenuhi syarat kepemimpinan sebagaimana syarat yang melekat pada kepemimpinan Nabi Muhammad SAW. ${ }^{3}$

Dari hasil wawancara penulis dengan salah satu masyarakat Kota Langsa Bapak Abdurrahman, beliau mengatakan sistem pemilu secara demokrasi yang sekarang kita gunakan banyak sekali mengandung kemaksiatan. salah satu contoh adalah berbagai cara dilakukan oleh para calon legislatif untuk memenangkan pemilu yaitu dengan memberikan uang atau barang

\footnotetext{
${ }^{3}$ http//www.PDFGolongan Putih. Politik Nahdatul Ulama dan Orde Baru.Diakses pada Tanggal 20 Juli 2018.
}

kepada masyarakat dengan tujuan agar masyarakat mencoblos mereka. bisa kita bayangkan, berapa banyak masyarakat Indonesia yang menerima uang haram itu. Bahkan, bagi caloncalon legislatif dan para pendukungnya yang tidak terpilih dalam pemilihan umum, tidak jarang mereka melakukan tindakan-tindakan anarkis yang imbasnya mengganggu ketentraman masyarakat. ${ }^{4}$

Hasil wawancara dengan Ulama Kota Langsa, bagi para ulama yang menyatakan golput adalah haram mereka mungkin menetapkan bahwa sikap ini dalam kondisi sekarang dapat menimbulkan mudharat dan bencana yang lebih besar bagi keselamatan umat, ketimbang ikut memilih sekalipun nanti akan kecewa karena ternyata si calon yang telah ditunjuk tersebut tidak amanah. Pada dasarnya tidak memilih atau golput juga merupakan suatu pilihan yang memiliki konsekuensi yang sama ketika kita memutuskan untuk memilih calon yang ada. Ikut mencoblos dalam pemilu mengandung resiko baik dan buruk, dikatakan baik kalau si calon tersebut bekerja sesuai amanah yang diberikan, dan disebut tidak baik kalau dia berkhianat.Sebaliknya tidak memilihpun mempunyai resiko yang buruk juga, gara-gara kita tidak memilih, maka yang terpilih justru orang-orang yang memiliki prinsip dan nilai bertentangan dengan apa yang kita anut.

${ }^{4}$ Hasil wawancara dengan Bapak Abdurrahman masyarakat Kota Langsa pada tanggal 10 Januari 2019. 


\section{SEJARAH GOLONGAN PUTIH}

Golongan putih atau lebih sering diungkapkan dengan Golput. Golput (golongan putih), adalah salah satu bentuk perlawanan terhadap praktik politik dari orang-orang yang kecewa terhadap penyelenggaraan yang dilakukan oleh negara, dengan cara tidak memilih partai atau legislator (dalam pemilu legislatif), atau presiden (dalam pemilu presiden). Sebagian besar mereka, menganggap para penyelenggara negara dan partai yang ada tidak mengeluarkan dan pro kebaikan berpolitik. Jadi dari pada memilih partai, lebih baik tidak memilih siapapun, anggapan mereka partaipartai yang ada akan berprilaku buruk bila memenangkan pemilu. ${ }^{5}$

Golongan putih bukanlah organisasi yang diatur oleh instrumen peraturan, golongan putih juga tidak dikoordinasikan melalui sistem manajement. Golongan putih sekedar penyebutan kepada akumulasi pribadi-pribadi yang tidak ikut pemilu atau mengikuti pemilu dengan cara merusak surat suara. Mereka tidak mengenal satu sama lain dan biasanya tidak dikenali, oleh orang terdekat sekalipun. Mungkin ada beberapa orang yang berani mendeklarasikan dirinya adalah golongan putih, Pada dasarnya sikap golongan putih yang sekarang ini banyak dilakukan msyarakat dalam pemilihan kepala daerah pilkada yang akan berpengaruh pada pemimpin yang terpilih, pemimpin semakin baik bila diiringi tingkat partisipasi politik masyarakat yang tinggi pada proses pemilihan seorang pemimpin.

Pemimpin yang terpilih juga akan dapat menjalankan roda pemerintahanya dengan tingkat percaya diri yang baik, jika diiringi dukungan yang tinggi oleh masyarakat. Tinggi rendahnya tingkat partisipasi politik masyarakat dapat dijadikan polo meter keberhasilan suatu negara ataupun daerah dalam proses penerapan demokrasi. Tingginya tingkat partisipasi dalam pemilihan umum juga dapat menunjukkan bahwa rakyat memahami masalah-masalah politik dan ingin terlibat dalam kegiatan politik. Sebaliknya rendahnya partisispasi rakyat dalam pemilu dianggap ancaman dari demokrasi. Partisipasi yang rendah dapat diasumsikan bahwa masyarakat tidak menaruh perhatian terhadap masalah kenegaraan. Dapat juga diasumsikan rendahnya partisipasi masyarakat sebagai bentuk ketidakpercayaan rakyat terhadap hasil pemilu yang dapat membawa perubahan.

Fenomena golongan putih juga dianggap sebagai ancaman bagi demokrasi. Dikatakan ancaman karena golongan putih dinilai tidak mendukung adanya pesta demokrasi. Bahkan besarnya angka masyarakat

5 Ricad M. Ketchum, Demokrasi sebuah Pengantar (Yogyakarta: Niagara, 2004), h. 80. 
tidak memilih, sangat sulit membangun logika bahwasanya yang kandidat pemenang pemilu merupakan representatif pilihan masyarakat, Hal ini juga tidak serta merta menjamin pemerintahan yang terbentuk mendapatkan dukungan yang maksimal dari masyarakat. ${ }^{6}$

Angka golongan putih di Indonesia dapat semakin tinggi bila mana masyarakat akan terus menerus mengalami kekecewaan disetiap pemilihan. Bentuk kekecewaanya pun sangatlah beragam. kepercayaan rakyat terhadap elit politik hampir mencapai titik nadir. Ini karena para pemimpin tidak lagi berpihak pada rakyat, akibatnya rakyat aprioki atau lebih tepatnya rakyat sudah bosan dengan suatu kejadian, dimana setiap kali dilakukan pemilihan umum masalah yang datang akan tetap sama. Maka dari itu ketika seseorang berfikir dan berasumsi bahwa setiap pemilihan umum selalu ada kekecewaan, jadi dapat dipastikan tingkat angka golongan putih menjadi pemenang pada pemilu 2014, baik dalam pemilu legislatif maupun pemilu presiden. $^{7}$

Dampak yang paling kongkrit dari minimnya partisipasi rakyat dalam pembangunan yaitu semakin berkurangnaya persentase pengguna hak suara dalam pemilu, misalnya semakin banyak rakyat yang tidak paham dan tidak percaya terhadap kegiatan pemilu dan sering juga

\footnotetext{
${ }^{6}$ Ibid., h. 82-83.

${ }^{7}$ Sigit Pamungkas, Pemilu, Prilaku Pemilih dan Kepatria (Yogyakarta: Institut Four Demokracy and Welfarism, 2010), h. 95-97.
}

disebut dengan pesta rakyat yang menghabiskan anggaran puluhan triliyun banyaknya, karena rakyat lebih diperlukan untuk memuluskan perjalanan sebuah partai dan para elitnya untuk melanggengkan kekuasaan, dari pada dipakai sebagai upaya mengartikan kepentingan masyarakat.

Golput dapat menguntungkan jika di negara yang politikusnya koruptif dan manipulatif disertai monuver yang licik sehingga mampu membentuk citra diri dan partai sebagai sosok pembela kepentingan rakyat. Pada umumnya ini di karenakan kaum golput enggan, acuhtak acuh, atau tahu diri bahwa dirinya golongan putih sehingga tidak terlalu vokal ketika mengkritik pemerintah hasil pemilu. ${ }^{8}$

Golongan putih jika dihadapkan pada sebuah sistem politik demokrasi tidak harus dinilai sebagai bentuk merosotnya partisipasi politik (politacal decay) dalam sebuah masyarakat. Partisipasi politik sendiri menurut anggapan para ilmuan politik, tidak harus diukur oleh meningkatnya jumlah orangorang yang datang ke TPS (tempat pemungutan suara). Untuk memberikan suara mereka tetapi cara pandang mereka yang aktif dalam dunia politik, termasuk ikut serta lembaga-lembaga sosial politik, keagamaan, organisasi profesi dan bisnis atau organisasi kemasyarakatan

\footnotetext{
${ }^{8}$ Ramlan Subakti, Memahami Ilmu Politik, (Jakarta: PT. Grasindo, 2007), h. 144.
} 
yaitu dalam bentuk dari sebuah partisipasi politik, hanya saja bisanya orang-orang dengan tingkat Intelektualitas atau penghasilan yang tinggi akan cenderung "aktif" berpartisipasi dengan memberikan suaranya dalam suatu pemilihan dibanding dengan mereka yang berpenghasilan di bawah rata-rata atau kurang baiknya tingkat pendidikan. ${ }^{9}$

Partai pemenang pemilu, dalam atmosfer politik yang koruptif dan manipulatif tersebut diuntungkan juga dari adanya golput argumentasi yang mirip dengan argumen perilaku politik kaum golput. Partai-partai konservatif yang kalah pemilu juga diuntungkan dengan adanya golput ini saat mereka sudah tidak mampu lagi meyakinkan kaum golput untuk memilih partainya. Mereka beranggapan bahwa tokoh-tokoh golput lebih baik berada di partai pemenang pemilu.

Hal ini disebabkan oleh kekuatan argumentatif yang umumya dimiliki oleh tokoh-tokoh golput. Realitas politik mengindikasikan bahwa kaum golput yang sadar dirinya memilih golput umumnya adalah kaum yang relatif memiliki pengetahuan poilitik yang limayan cerdas, daya kritis yaang tajam, serta status sosil-ekonomi yang menengah atas. $^{10}$

Untuk mengatasi dan mengurangi jumlah golput, instansi

9 Abdul Yani, Sosiologi Kelompok dan Masalah Sosial, (Jakarta: Fajar Agung, 1987), h. 170.

10 Farma, Teori Politik Modern (Jakarta: PT. Raja Grafindo Prasada, 2007), h. 260. terkait terus melakukan penyuluhan bahkan sampai jauh-jauh. Penyuluhan ini sering kali ditambahi dengan adegan atau penampilan yang menarik sehingga masyarakat mau untuk memperhatikan, sebenarnya penyuluhan saja tidak lah cukup, karana yang terpenting adalah bagaimana calon pemimpin tersebut mampu membuktikan kenerja setelah terpilihnya nanti. Karena sebenarnya masyarakat cenderung tidak peduli tentang siapa pemimpinnya tersebut. ${ }^{11}$

Namun demikian partisipasi politik yang tinggi bukan pula jaminan sebuah negara itu indikator demokratisasinya meningkat dengan baik. Namun yang jelas bahwa setiap usaha to get out the vote terutama jika melihat persentase golongan putih mengalami peningkatkan, tentunya harus terus diupayakan agar ikut serta dalam aktivitas politik, minimal ikut serta dalam aktivitas politik, minimal ikut serta dalam memberikan suaranya pada saat pilkada. Pilkada, selain sebagai sarana untuk memiliki pimpinan juga bisa menjadi bagian dari peningkatan pendidikan politik masyarakat secara lebih baik, memberikan suara pada saat pemilu, justru akan mempengaruhi kebijakankebijakan pemerintah secara lebih luas, jika suara-suara para pemilihan berjumlah banyak, karena suara pada setiap individu tidak pernah akan berarti apa-apa kecuali ketika

11 Michael Rus dan Althoff, Pengantar Sosiologi Politik (Jakarta: PT. Raja Wali, 1989), h. 131. 
diakumulasi sehingga memenangkan salah satu kontestan. ${ }^{12}$

Jika diartikan secara sederhana golongan putih dapat diartikan sebagai suatu tindakan yang dilakukan secara sengaja dan sadar untuk menolak memberikan hak suaranya dalam pemilu. Dengan demikian orang-orang yang berhalangan hadir di tempat pemungutan suara hanya karena alasan tertantu, seperti jauhnya TPS atau terluput dari pendaftaran, otomatis dikeluarkan dari kategori golongan putih.

Dilansir bahwasanya dari tahun ketahun angka masyarakat yang tidak memilih atau golongan putih dari pemilu kepemilu terus meningkat. Oleh karena itu harus ada upaya nyata yang dilakukan untuk meminimalisir angka masyarakat yang tidak memilih dalam pemilu karena kualitas pemilu secara tidak langsung juga dilihat dari legitimasi pemimpin yang dipilih langsung oleh rakyat. $^{13}$

Bedasrkan penafsiran hukum, ketentuan hukum terhadap golput terbagi menjadi dua kelompok. Adapun kelompok yang berpendapat golput dapat di pidana bedasarkan UU Nomor 8 tahun 2012 tentang pemilu legislatif.

\section{Pasal 283}

Setiap orang yang membantu pemilih yang dengan sengaja memberitahukan pilihan pemilih

\footnotetext{
12 Ibid., h. 132.

${ }^{13}$ M.Budiarjo, Demokrasi di Indonesia: Demokrasi Parlementer dan Demokrasi Pancasila
}

kepada orang lain sebagaimana dimaksud dalam pasal 157 ayat (2) di pidana dengan kurungan paling lama 1 (satu) tahun dan denda paling banyak Rp. 12.000.000,00 (dua belas juta rupiah).

\section{Pasal 157}

1. Pemilih tunanetra, tunadaksa, dan yang mempunyai halangan fisik lain pada saat memberikan suaranya di TPS dapat di bantu oleh orang lain atas permintaan pemilih.

2. Orang lain yang membantu pemilih dalam memberikan suara sebagaimana yang di maksud pada ayat (1) wajib merahasiakan pilihan pemilih.

3. Ketentuan lebih lanjut mengenai pemberian bantuan kepada pemilih diatur dengan peraturan KPU. Kaitannya dengan golput adalah ketika survei atau jajak pendapat itu juga terkait dengan golput. Contohnya jajak pendapat yang menyebutkan bahwa persentase golput sehingga memengaruhi orang untuk memilih goplut alih-alih memilih kontestan pemilu.

\section{Pasal 291}

Setiap orang yang mengumumkan hasil survei atau jajak pendapat tentang pemilu dalam massa tentang sebagaimana dimaksudkan dalam pasal 247 ayat (2), dipidana dengan pidana kurung paling lama 1 (satu) tahun dan denda paling banyak Rp. 12.000.000,00 (dua belas juta rupiah).

(Jakarta: PT. Gramedia Pustaka Utama, 1996), h. 183. 


\section{Pasal 308}

Setiap orang yang dengan sengaja menggunakan kekrasan, dan menggalangi seseorang yang akan melakukan haknya untuk memilih, melakukan kegiatan yang menimbulkan gangguan ketertiban dan ketentraman pelaksanaan pemungutan suara, atau menggagalkan pemungutan suara dipidana dengan pidana penjara paling lama 2 (dua) tahun dan denda paling banyak Rp. 24.000.000,00 (dua puluh empat juta rupiah).

Pasal-pasal diatas berisikan tentang pidana bagi orang yang mengajak golput dengan pemaksaan, baik secara fisik, psikis (karena kedudukannya sehingga memiliki kuasa), maupunsecara finansial. Namun, apabila seorang golput mengajak orang lain tanpa paksaan, misalnya memberikan opini UU tidak mengaturnya secara eksplist. ${ }^{14}$

Pengertian golongan putih secara umum adalah fenomena dalam demokrasi golongan putih atau disebut juga No Voting Deasion selalu ada pada setiap pesta demokrasi, dimanapun terutama yang menggunakan sistem pemilihan langsung (direct voting), mereka (para pemilih) apabila berkeputusan untuk tidak memilih salah satu dari kontestan yang tersedia pada kertas suara ketika dilakukan pemungutan suara. Apabila cara untuk memilih dilakukan dengan mencoblos logo/ foto maka pemilihan tidak mencoblos pada tempat yang disediakan sehingga kartu suara dinyatakan tidak sah. Jika untuk memilih digunakan dengan memberikan coretan atau tanda centang, maka pemilih tidak memberikan tanda centang bukan pada tempat yang disediakan sehingga kartu suara menjadi tidak sah. ${ }^{15}$

Pendukung golongan putih tidak hanya berasal dari satu garis partai melainkan seluruh partai dan organ-organ sosial. Semuanya melihat dengan jelas betapa massif retorika politik yang dibangun untuk mengelabui rakyat, karenanya parlemen dan pemerintah dinilai penyebab lahirnya diskriminasi sosial, politik, ekonomi, hukum dan budaya di negeri ini. ${ }^{16}$

\footnotetext{
15 Syaifudin Jurdi, Pemikiran Politik Islam di Indonesia., h. 16-17.

${ }^{16}$ Fadillah Putra, Partai Politik dan Kebijakan Publik., h. 90-91.
} 
Maka prilaku golongan putih secara umum dimaksudkan sebagai simbol protes atas sistem yang tidak adil sisitem yang hanya menguatkan posisi kelompok minoritas (elit) dan mengabaikan subtansi demokrasi yang bertujuan membangun peradaban masyarakat yang lebih baik, yang terpenting lagi adalah golongan putih ditunjukkan pada tiadanya amanah dari elit dan pemimpin bangsa dalam menjalankan roda kekuasaanya protes tersebut ditunjukkan pada pemerintah yang korup dan tidak akuntabel maka kondisi demikian menyebutkan ketidakpercayaan masyarakat luas. ${ }^{17}$

Istilah golongan putih pertama kali muncul menjelang pemilu 1971 istilah ini sengaja dimunculkan oleh Arief Budiman dan kawan-kawan sebagai bentuk perlawanan terhadap organisasi pemerintah dan ABRI (sekaang TNI) yang sepenuhnya memberikan dukungan politis kepada Golkar. Organisasi ini ditunjukkan dengan memaksakan (dalam bentuk ancaman) seluruh jajaranaparatur pemerintahan termasuk keluarga

17 Martin Jimung, Partai Lokal dan Pemerintahan Daerah dalam Persfektif Otonomi Daerah (Yogyakarta: Yayasan Pustakaan Nusantara, 2005), h. 77 . untuk sepenuhnya memberikan pilihan pada golkar.

Organisasi seperti ini dianggap menyimpang dari nilai dan kaidah demokrasi dimana kekuasaan sepenuhnya ada ditangan rakyat yang memilih. Ketika itu Arief Buiman mengajak masyarakat untuk menjadi golongan putih dengan cara tertap mendatangi tempat pemungutan suara (TPS) ketika melakukan pencoblosan bagian yang dicoblos bukan pada tanda gambar partai politik akan tetapi pada bagian yang bewarna putih maksudnya tidak mencoblos tepat pada tanda gambar yang dipilih itu artinya jika mencoblos tidak tepat pada tanda gambar maka kertas suara tersebut dianggap tidak sah. ${ }^{18}$

Tokoh yang terkenal memimpin gerakan goput adalah Arief Budiman sepanjang order baru. Beliau dianggap pembangkang dan sulit mendapatkan pekerjaan walau seorang doktor lulusan Harvad. Ia kemudian menjadi dosen di Universitas Kristen Stya Wacana (UKSW), Salatiga, dan universitas melbourne, namun pencetus istilah

\footnotetext{
${ }^{18}$ Soetedjo, Dinamika Dunia Politik (Jakarta: Pustaka Nusantara, 2001), h. 35.
} 
"golput" ini sendiri adalah Imam waluyo. Di pakai istilah " putih" karena gerakan ini mengajurkan agar menjoblos bagian putih pada kertas atau surat suara. ${ }^{19}$

Di luar gambar partai politik, peserta pemilu, ini bagi yang datang ke bilik suara namun di masa itu jarang ada yang berani tidak datang ke tempat pemungutan suara (TPS) karena akan ditandai. Baru saja orde baru selesai melakukan konsolidasi dengan melibas habis bukan saja pendukung PKI (Partai Komunis Indonesia) tetapi juga para pendukung rezim orde lama dan para soekarnois, pemilu 1971 adalah sarana bagi rezim orde baru untuk mementapkan kekuasaannya di negara ini. ${ }^{20}$

Kebanyakan tokoh pencetus golput sendiri adalah angkatan 66 , ini adalah sebutan bagi mahasiswa dan pemuda yang ikut dalam demontrasi massa besar menuntut penjungkalan Soekarno, sebagai dari tokoh angkatan 66 diakomodasikan orde baru ke dalam sistem, mereka ada

\footnotetext{
${ }^{19}$ Ibid., h. 37.

${ }^{20}$ Ibid., h. 38.

${ }^{21}$ Soetedjo, Dinamika Dunia Politik., h. 3638.
}

yang menjadi DPR-GR (gerakan perwakilan rakyat gotong royong). Bahkan kemudian ada yang menjadi menteri, namun yang tetap kritis melawan rezim baru yang di anggap mengingkari perjanjian yang berlaku. $^{21}$

Jika dicermati dari data hasil pemilu kepemilu maka ada kecenderungan peningkatan persentasenya namun alasan yang mendasari masyarakat untuk melakukan tindakan golongan putih mengalami pergeseran dengan kesadaran masyarakat tentang hakhak. Politik yang semakin tinggi dan sikap kritis yang semakin menguat gerakan golongan putih dapat diminimalisir hanya dengan cara: yang pertama penyelenggaraan pemilu (KPU) harus senantiasa profesional dalam menjalankan kinerja dan ffungsinya, khususnya dalam menyiapkan proses dan tahapan pemilu. Kedua tingkat kepercayaan masyarakat terhadap lembaga politik, baik itu partai politik parlemen maupun lembaga eksekutif dan yudikatif harus dibangun kembali dengan menampilkan perfomance dan kinerja yang baik sehingga masrakat kembali memiliki harapan bhawa suara mereka dibilik suara tidak akan sia-sia. ${ }^{22}$

\footnotetext{
${ }^{22}$ Rafael Ragga Maran, Pengantar Sosiologi Politik., h. 145 .
} 


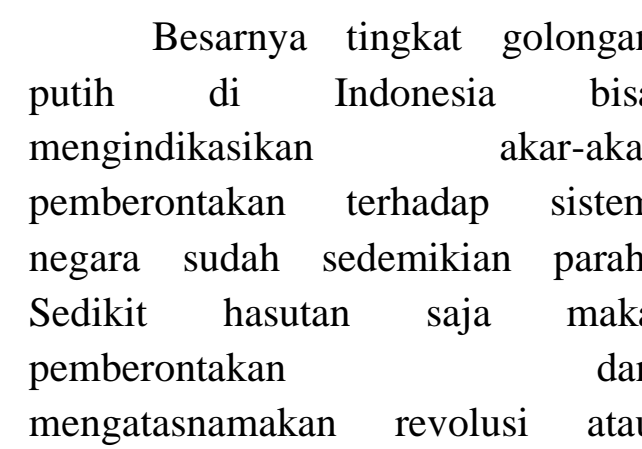
apapun akan menjadi ancaman serius bagi keutuhan NKRI. Itulah sebabnya beberapa kelompok sangat gencar mengkampanyekan anti golongan putih, agar hura-hura yng pernah mewarnai sejarah bangsa ini tidak terulang kembali yang mana belakangan ini tidak terulang kembali, yang mana belakangan ini semakin dikhawatirkan dengan acuhnya bangsa atau malah ikut membesarkan ideologi golongan putih. $^{23}$

Memilih dalam pemilu adalah hak bagi seluruh warga negara Indonesia yang telah memiliki KTP. Namun bagi mereka yang memutuskan untuk tidak memilih apapun alasannya alias golput sebenarnya tidak menyalahi aturan perundang-undangan manapun sehingga tidak dapat di pidana meskipun begitu, pasal 308 UU No.8 tahun 2012 tentang pemilu memberikan ruang bagi penegak hukum atau menjerat siapa pun yang mengajak orang lain untuk golput. ${ }^{24}$

${ }^{23}$ Gauzi Saydam, Dari blik Suara ke Masa Depan Indonesia, Potret Konflik Pasca Pemilu dan Nasib Reformasi (Jakarta: PT. Raja Grafindo Persada, 1999), h. 5.

\section{Persepsi Ulama Kota Langsa Tentang Golongan Putih}

Golput (golongan putih) adalah salah satu bentuk perlawanan terhadap praktik politik dari orangorang yang kecewa terhadap penyelenggaraan negara dengan cara tidak memilih partai atau legislator (dalam pemilu legislatif) atau Presiden (dalam pemilu Presiden).

Tidak diperbolehkannya golput (haramnya golput) apabila terdapat seorang pemimpin yang tidak memenuhi syarat-syarat yang telah ditentukan untuk menjadi pemimpin.Syarat-syarat tersebut adalah sebagai berikut:

1) Memilih pemimpin dalam Islam adalah kewajiban untuk menegakan imamah dan imarah dalam kehidupan bersama.

2) Memilih pemimpin yang beriman dan bertaqwa, jujur (sidiq), terpercaya (amanah), aktif dan aspiratif (tablig), mempunyai kemampuan (fathonah), dan memperjuangan

kepentingan umat Islam hukumnya adalah wajib.

\footnotetext{
${ }^{24}$ Ibid., h. 10.
} 
Memilih pemimpin yang tidak memenuhi syarat-syarat sebagaimana disebutkan diatas atau tidak memilih sama sekali padahal terdapat calon yang memenuhi syarat hukumnya adalah haram.

Berdasarkan hasil wawancara mengenai persepsi Ulama Kota Langsa mengenai Golongan Putih yaitu sebagai berikut:

Heriansyah selaku Tengku Dayah Mu'arif al-Aziziyah, ia mengatakan golput (golongan putih) itu tidak boleh dan sangat diharamkan. Di dalam agama memilih adalah kewajiban disetiap Negara itu harus ada pemimpin, dan setiap warga Negara Indonesia pasti mempunyai hak pilih masing-masing. dan ia mengatakan kenapa harus ada golput kalau pemimpin yang mencalonkan diri sudah memenuhi syarat menjadi seorang pemimpin. Menggunakan hak suara dalam memilih bukan dalam rangka mencari pemimpin yang akan menegakkan Islam, namun rangka meminimalkan ruang gerak para penjahat dan musuh Islam. $^{25}$

${ }^{25}$ Hasil wawancara dengan Heriansyah (Tengku Dayah di Mu'arif al-Aziziyah) pada Tanggal 08 Juli 2019.
Dapat disimpulkakn, golput (golongan putih) itu tidak boleh dan sangat diharamkan selama calon pemimpin tidak memenuhi syarat menjadi seorang pemimpin.

Dr. Zulkarnain, MA selaku Ketua MPU Kota Langsa, ia mengatakan golput adalah haram. Dalam konsep Islam golput identik dengan orang yang tidak bertanggung jawab. Mereka mengabaikan hak pilihnya sebagai warga Negara, golput lebih besar kemudharatannya dan di dalam Islam ada istilah mencari mudharat itu tidak didahulukan yaitu dalam Islam lebih mencari manfaat, maka golput itu harus di tinggalkan. ${ }^{26}$

Dapat disimpulkakn, golput (golongan putih) adalah haram, karena dalam konsep Islam golput identik dengan orang yang tidak bertanggung jawab.

Tengku Abdul Wahab Ali selaku Ketua Komisi MPU, ia mengatakan golput (golongan putih) dimata agama tidaklah benar, dalam sudut pandang Islam bahwa tindakan

\footnotetext{
${ }^{26}$ Hasil wawancara denganDr. Zulkarnain (Ketua MPU Kota Langsa) pada Tanggal 11 Juli 2019.
} 
golput bagian dari pelanggaran. Masyarakat yang melakukan golput itu dengan sengaja maka itu salah. ${ }^{27}$

Dapat disimpulkakn, golput (golongan putih) dimata agama tidak benar dan dalam sudut pandang Islam golput bagian dari pelanggaran.

Syekh Muhajir, LLM selaku Pimpinan Dayah Darul Huda Kota Langsa, Beliau mengatakan golput itu tidak boleh, memilih hak dan kewajiban bagi kita semua masyarakat di Indonesia. Kita tidak boleh memaksa orang lain untuk memilih, masalah memberikan suara dalam pemilu adalah masalah yang berbeda, beda tergantung dari waktu tempat dan keadaan masalah tidak memilih tidak bisa dipikul rata untuk setiap keadaan, ia juga mengatakan alasan tidak boleh golput yaitu tidak ada maslahat yang dicapai dalam pemilu, bahkan orang yang mengikutinya bukan menghilangkan bahaya yang lebih ringan namun sebenarnya dia telah terjerumus dalam bahaya yang lebih besar. Kalau pemimpin yang kita pilih bukan orang Islam maka untuk apa kita pilih, kita

${ }^{27}$ Hasil wawancara dengan Tengku Abdul Wahab Ali (Ketua Komisi MPU) pada Tanggal 11 Juli 2019. sebagai orang Islam harus memilih calon pemimpin yang memperjuangkan hukum Islam. Jadi kalau kita mau golput ya kenapa tidak, kalau pemimpin yang mencalonkan diri tidak mensejahterakan rakyatnya. jadi untuk apa tidak membela Islam kita akan memberikan hak pilih kita untuk memajukan Islam. ${ }^{28}$

Dapat disimpulkakn, golput itu tidak boleh karena tidak ada maslahat yang dicapai dalam pemilu, bahkan orang yang mengikutinya bukan menghilangkan bahaya yang lebih ringan namun sebenarnya dia telah terjerumus dalam bahaya yang lebih besar.

Dari semua hasil wawancara mengenai argumen Ulama Kota Langsa tentang golongan putih mengatakan golput boleh saja, karena golput itu hak, sekaligus kewajiban bagi Negara yang baik. Jika seseorang tidak mau menggunakan hak pilihnnya tidak bisa dipaksakan juga tetapi sebagai warga negara yang bertanggung jawab, masyarakat wajib memilih karena satu suara saja sangat berguna bagi kehidupan bangsa kedepannya. Sebagai warga negara yang baik sepatutnya harus

\footnotetext{
${ }^{28}$ Hasil wawancara dengan Syekh Muhajir, LLM (Pimpinan Dayah Darul Huda) pada Tanggal 12 Juli 2019.
} 
bertanggung jawab dan ia tidak boleh meninggalkan hak pilihnya kerena ia sudah mengakui bahwa demokrasi sebagai cara untuk bernegara.

\section{Argumen Ulama Kota Langsa Tentang Golongan Putih}

Golongan putih dapat diartikan sebagai suatu tindakan yang dilakukan secara sengaja dan sadar untuk menolak memberikan hak suaranya dalam pemilu. Dengan demikian orang-orang yang berhalangan hadir di (TPS) hanya karena alasan tertantu, seperti jauhnya TPS atau terluput dari pendaftaran, otomatis dikeluarkan dari kategori golongan putih.

Dari tahun ketahun angka masyarakat yang tidak memilih atau golongan putih dari pemilu kepemilu terus meningkat. Oleh karena itu harus ada upaya nyata yang dilakukan untuk meminimalisir angka masyarakat yang tidak memilih dalam pemilu karena kualitas pemilu secara tidak langsung juga dilihat dari legitimasi pemimpin yang dipilih langsung oleh rakyat.

${ }^{29}$ Hasil wawancara dengan Mustafa Ya'qub (Tengku Dayah Darul Muta'alimun) pada Tanggal 12 Juli 2019.
Dalam pemilihan umum (pemilu) banyak orang-orang yang tidak memilih atau menggunakan hak suaranya dalam memilih atau lebih dikenal dengan golput, yang menyebabkan keberhasilan dalam pemilu ini kurang befektif dari hasil yang di dapatkannya.

Berdasarkan hasil wawancara mengenaiargumen Ulama Kota Langsa tentang golongan putih yaitu sebagai berikut :

$$
\text { Mustafa Ya'qub selaku }
$$
Tengku Dayah Darul Muta'alimun, ia mengatakan golput boleh saja, ia menegaskan bahwa tidak berpartisipasi dalam proses pemilu merupakan hak politik warga negara. Namun demikian sebagai warga yang baik ada kewajiban moral untuk mengikuti seruan fatwa tersebut. ${ }^{29}$

Dapat disimpulkan golput boleh, dalam proses pemilu merupakan hak politik warga Negara.

Kamarullah selaku Pimpinan Dayah Darul Muta'alimun, ia mengatakan sebagian ulama mungkin memandang bolehnya memberikan suara dalam pemilu bahkan kewajibannya, dan mengharamkannya jika tidak ikut memilih. Akan tetapi ada juga 
sebagian ulama yang mengatakan bahwa boleh untuk golput. kalau menurut beliau boleh golput karena memilih dalam pemilu ini adalah hak dan kewajiban bagi kita semua. alasan ia mengatakan boleh golput harus bisa melihat pemimpin yang akan menjadi masa depan apakah memenuhi syarat sebagai seorang pemimpin, seorang pemimpin harus taat pada agama, dan kita sebagai seorang muslim harus memilih pemimpin yang berpegangan teguh pada al quran dan hadis. ${ }^{30}$

\section{Dapat disimpulkanboleh} golput, akan tetapi harus bisa melihat pemimpin yang akan menjadi masa depan apakah memenuhi syarat sebagai seorang pemimpin, seorang pemimpin harus taat pada agama, dan kita sebagai seorang muslim harus memilih pemimpin yang berpegangan teguh pada al quran dan hadis.

Dr. Suhaili Sufyan, Lc. MA selaku Dosen IAIN Langsa, ia mengatakan golput itu hak, sekaligus kewajiban bagi negara yang baik. Jika seseorang tidak mau menggunakan hak pilihnnya tidak bisa dipaksakan juga tetapi sebagai warga negara yang bertanggung jawab, masyarakat wajib memilih karena satu suara saja sangat berguna bagi kehidupan bangsa

\footnotetext{
${ }^{30}$ Hasil wawancara dengan Kamarullah (Pimpinan Dayah Darul Muta'alimun) pada Tanggal 12 Juli 2019.
}

kedepannya. maka tidak baik bagi masyarakat Indonesia untuk memilih golput, jika suara dia sangat menentukan kehidupan bangsa dan dia sengaja untuk golput maka itu salah satu perbuatan dosa. Secara demokrasi itu adalah hak ia untuk menggunakannya atau tidak. satu suara sangat penting bagi seorang pemimpin. Jika masyarakat dengan sengaja melakukan golput itu sama saja ia memberi peluang bagi seorang pemimpin yang memang tidak baik, jika dikatakan berdosa $100 \%$ tidak juga, dikatakan tidak berdosa itu tergantung kondisinya seperti apa, akan tetapi jika telah mengetahui cara demokrasi itu seperti apa sepatutnya harus bertanggung jawab dan ia tidak boleh meninggalkan hak pilihnya kerena ia sudah mengakui bahwa demokrasi sebagai cara untuk bernegara. $^{31}$

Dapat disimpulkan golput itu hak, sekaligus kewajiban bagi negara yang baik. Jika seseorang tidak mau menggunakan hak pilihnnya tidak bisa dipaksakan juga tetapi sebagai warga negara yang bertanggung jawab, masyarakat wajib memilih karena satu suara saja sangat berguna

\footnotetext{
${ }^{31}$ Hasil wawancara dengan Dr. Suhaili Sufyan, Lc, MA (Dosen IAIN Langsa) pada Tanggal 15 Juli 2019.
} 
bagi kehidupan bangsa kedepannya. Sebagai warga negara yang baik sepatutnya harus bertanggung jawab dan ia tidak boleh meninggalkan hak pilihnya kerena ia sudah mengakui bahwa demokrasi sebagai cara untuk bernegara.

Dari semua hasil wawancara mengenaiargumen ulama Kota Langsa tentang golongan putihmengatakan golput boleh saja, karena golput itu hak, sekaligus kewajiban bagi negara yang baik. Jika seseorang tidak mau menggunakan hak pilihnnya tidak bisa dipaksakan juga tetapi sebagai warga negara yang bertanggung jawab, masyarakat wajib memilih karena satu suara saja sangat berguna bagi kehidupan bangsa kedepannya. Sebagai warga negara yang baik sepatutnya harus bertanggung jawab dan ia tidak boleh meninggalkan hak pilihnya kerena ia sudah mengakui bahwa demokrasi sebagai cara untuk bernegara.

\section{A. KESIMPULAN}

Persepsi ulama Kota Langsa mengenai golongan putih yaitu golput tidak boleh karena diharamkan selama calon pemimpin tidak memenuhi syarat menjadi seorang pemimpin, dalam konsep Islam golput identik dengan orang yang tidak bertanggung jawab. Golput (golongan putih) dimata agama tidak benar dan dalam sudut pandang Islam golput bagian dari pelanggaran dan golput tidak boleh karena tidak ada maslahat yang dicapai dalam pemilu. Argumen ulama di Kota Langsa tentang golongan putih yaitu golput dibolehkan, karena golput itu hak, sekaligus kewajiban bagi negara yang baik. Jika seseorang tidak mau menggunakan hak pilihnnya tidak bias dipaksakan juga tetapi sebagai warga negara yang bertanggung jawab, masyarakat wajib memilih karena satu suara saja sangat berguna bagi kehidupan bangsa kedepannya. Sebagai warga negara yang baik sepatutnya harus bertanggung jawab dan ia tidak boleh meninggalkan hak pilihnya kerena ia sudah mengakui bahwa demokrasi sebagai cara untuk bernegara. 


\section{DAFTAR PUSTAKA}

Gandang Ismara, Memahami Eksistensi Golongan Putih dalam Demokrasi, dalam http//lanskup artikel. Blogspot.com/2008/10/memahami-eksistensi -golongan putihdalam. html. Diakses pada Tanggal 15 Juli 2009.

http//www.kompas.com. Diakses Pada Tanggal 10 Juli 2008.

http//www.PDFGolongan Putih. Politik Nahdatul Ulama dan Orde Baru.Diakses pada Tanggal 20 Juli 2018.

Hasil wawancara dengan Bapak Abdurrahman masyarakat Kota Langsa pada tanggal 10 Januari 2019.

M.Budiarjo, Demokrasi di Indonesia: Demokrasi Parlementer dan Demokrasi Pancasila (Jakarta: PT. Gramedia Pustaka Utama, 1996).

Subakti Ramlan, Memahami Ilmu Politik, (Jakarta: PT. Grasindo, 2007).

Syarifuddin Azwar, Metode Penelitian (Yogyakarta: Pustaka Pelajar, 1998).

Gauzi Saydam, Dari blik Suara ke Masa Depan Indonesia, Potret Konflik Pasca Pemilu dan Nasib Reformasi (Jakarta: PT. Raja Grafindo Persada, 1999).

Martin Jimung, Partai Lokal dan Pemerintahan Daerah dalam Persfektif Otonomi Daerah (Yogyakarta: Yayasan Pustakaan Nusantara, 2005). 
